$\underline{\xi}=-m$

\title{
Paracetamol induced hepatic toxicity and amelioration by cinnamon in rats
}

\author{
Ashraf Elkomy ${ }^{1}$, Mohamed Aboubakr ${ }^{1}{ }^{*}$, Ahmed Soliman ${ }^{3}$, Ahmed Abdeen ${ }^{2}$, Afaf Abdelkader ${ }^{4}$, Haitham Hekal ${ }^{1}$ \\ ${ }^{1}$ Department of Pharmacology, Faculty of Veterinary Medicine, Benha University, 13736, Moshtohor, Toukh, Qalioubeya, Egypt \\ ${ }^{2}$ Department of Forensic medicine and toxicology, Faculty of Veterinary Medicine, Benha University, Egypt \\ ${ }^{3}$ Department of pharmacology, Faculty of Veterinary Medicine, Cairo University, Egypt \\ ${ }^{4}$ Department of forensic medicine and clinical toxicology, Faculty of Medicine, benha university, Egypt \\ *Corresponding author E-mail: mohamed.aboubakr@fvtm.bu.edu.eg
}

\begin{abstract}
The study was designed to evaluate the hepato-protective activity of aqueous extract of cinnamon in acute experimental liver injury induced by paracetamol. Twenty four male albino rats were randomly divided into four groups (six rats in each). Group I rats received distilled water for 15 days and served as a vehicle control. The animals in the group II were given single oral administration of paraceta$\mathrm{mol}(1 \mathrm{~g} / \mathrm{kg}), 1 \mathrm{~h}$ after last distilled water administration and acts as paracetamol toxic control group. Groups III and IV received aqueous extract of cinnamon (200 and $400 \mathrm{mg} / \mathrm{kg}$ bwt), respectively, once daily for 15 consecutive days followed by a single oral administration of paracetamol $(1 \mathrm{~g} / \mathrm{kg}), 1 \mathrm{~h}$ after the last cinnamon dose administration. The degree of hepatoprotection was measured using liver enzymes (Aspartate aminotransferase (AST), Alanine aminotransferase (ALT), bilirubin, albumin, and lipid profile levels. Also, histopathological examinations of liver were done. The significantly disturbed liver functions by paracetamol toxicity were restored to nearly normal values by administration of cinnamon. Also, the change in biochemical parameters in groups received paracetamol alone was modified towards the normal values in groups given paracetamol and cinnamon. Histopathological effect of paracetamol on liver was also markedly decreased by co-administration of cinnamon. Our findings concluded that cinnamon aqueous extracts possessed hepatoprotective activity against paracetamol induced hepatic toxicity in rats.
\end{abstract}

Keywords: Cinnamon; Hepato-Protective; Paracetamol; Rats.

\section{Introduction}

The importance of traditional systems of medicine and of certain traditional medical practices has now been recognized all over the world. Today, it is important to have pragmatic approach and an intelligent to evaluate the drugs originated from herbs. Therefore, it is important for Pharmacologists to obtain a lot of information from traditional healers, about their remedies and for extraction of active principles for development into drugs (Muthuraman et al., 2011).

Cinnamon (Cinnamomum zeylanicum) is an evergreen tree and wildy grows in Sri Lanka, Madagascar, Indochina and India. The inner bark of the tree has been used as flavoring for foods and in ethno-medicine (Bakkali et al., 2008). In addition to its culinary uses, cinnamon has been used in traditional herbal medicine to treat different health conditions (Gruenwald et al., 2010).

Some studies showed that cinnamon extracts and its constituents also effective in the treatment of cancer (Nishida et al., 2003), insecticidal (Yang et al. 2005), hypotensive (Preuss et al., 2006), antioxidant and antimutagenic activities (Jayaprakasha et al., 2007), cholesterol-lowering effects (Subash Babu et al., 2007), antimicrobial action (Carmo et al., 2008) and anti-inflammatory effect (Tung et al., 2008).

The liver is the largest internal organ in the body and played a very important role in the detoxification of harmful and toxic substances. It was responsible for maintaining homeostasis of the body and has regulatory effect on the many important metabolic functions in the body (Mayuren et al., 2010).

Paracetamol, the widely used antipyretic analgesic drug, however it was considered a safe drug, it produces renal failure and hepatic necrosis when given in a high doses (Ahmed and Khater, 2001; Abraham, 2005)

Hence, the goal of the present research work was to study if the hepatic toxicity induced by paracetamol can be ameliorated by the use of cinnamon aqueous extract.

\section{Materials and methods}

\subsection{Medicinal plant}

Cinnamon zeylanicum., Family Lauraceae barks was purchased from a local market of medicinal plants and herbs, Cairo, Egypt. The dried cinnamon was grinded to a fine powder and preserved till preparation of cinnamon aqueous extract.

\subsection{Preparation of aqueous extract}

A total of $200 \mathrm{~g}$ of each powder of cinnamon barks were dissolved in $1 \mathrm{~L}$ of distilled water and boiled for $10 \mathrm{~min}$, cooled and filtered through double layers of gauze to obtain cinnamon aqueous extracts 20\% (Shalaby and Hamowieh, 2010). 


\subsection{Experimental rats}

Male Wistar rats (170-200 g) were obtained from the Anima House, Faculty of Veterinary Medicine, Benha University, Egypt. They were fed on a standard pellet diet and tap water was provided ad libitum and were kept in plastic cages at room temperature $22-25^{\circ} \mathrm{C}$. Experimental rats were acclimatized to the environment for two week prior to experimental use. This study was approved by the Ethics Committee on animals.

\subsection{Experimental protocol}

Male Wistar rats (Twenty four) were divided into four groups of six rats each. Group I rats received distilled water for 15 days and served as a vehicle control. The animals in the group II served as paracetamol toxic control and were administered a single oral dose of paracetamol (1 g/kg) (Gad et al., 2013), $1 \mathrm{~h}$ after last dose of distilled water administration. Groups III and IV received aqueous extract of cinnamon (200 and $400 \mathrm{mg} / \mathrm{kg}$ ), respectively, once daily for 15 consecutive days followed by a single oral administration of paracetamol $(1 \mathrm{~g} / \mathrm{kg}), 1 \mathrm{~h}$ after the last cinnamon dose administration.

\subsection{Blood samples for biochemical estimation}

After $48 \mathrm{~h}$ of paracetamol administration, rats were anesthetised by diethyl ether. Blood samples from each rat was collected by puncturing retro-orbital plexus in sterilized dry centrifuge tube and kept to coagulate for $30 \mathrm{~min}$ at room temperature. The clear sera obtained after centrifugation (3000 rpm for $15 \mathrm{~min}$ ) was stored at
$4{ }^{\circ} \mathrm{C}$ and used for further biochemical estimation which was performed by using ready-made kits from Diamond diagnostics company (Egypt).

\subsection{Histopathological study}

Following complete necropsy of the experimental male rats, small fresh specimens from liver were collected and rapidly fixed in 10 $\%$ formalin solution for at least $24 \mathrm{hrs}$. The stain was Haematoxylin and Eosin (H.E.). Histopathology wss performed according to the method described by Harries (1989).

\subsection{Statistical analysis}

The data were expressed as (mean \pm SE) and analyzed using SPSS (Statistical Package for the Social Sciences, version 16.0, Illinois, Chicago, USA) and differences between the averages were examined by Duncan's multiple range test.

\section{Results}

Oral administration of paracetamol at a dose of $1 \mathrm{~g} / \mathrm{kg}$ caused a significant increase in liver parameters (ALT, AST, bilirubin, cholesterol, triglycerides, LDL-chol) and a significant decrease in albumin and HDL-chol in comparison with control values. In cinnamon treated groups these biochemical parameters were returned towards the normal values. These biochemical parameters were recorded in table (1).

Table 1: Effect of Oral Administration of Aqueous Extract of Cinnamon (200 and $400 \mathrm{Mg} / \mathrm{Kg} \mathrm{B}$.Wt. on Liver Parameters in Paracetamol Induced Hepatic Toxicity in Rats ( $\mathrm{N}=6)$

\begin{tabular}{|c|c|c|c|c|}
\hline Parameters & Control & Paracetamol & $\begin{array}{l}\text { Cinnamon extract } \\
(200 \mathrm{mg} / \mathrm{kg} \mathrm{bwt}) \\
+ \text { paracetamol }\end{array}$ & $\begin{array}{l}\text { Cinnamon extract } \\
(400 \mathrm{mg} / \mathrm{kg} \text { bwt }) \\
+ \text { paracetamol }\end{array}$ \\
\hline $\begin{array}{l}\text { AST } \\
(\mathrm{U} / \mathrm{L})\end{array}$ & $48.53 \pm 1.54^{\mathrm{c}}$ & $69.05 \pm 2.05^{\mathrm{a}}$ & $58.49 \pm 2.36^{\mathrm{b}}$ & $56.01 \pm 2.19^{\mathrm{b}}$ \\
\hline $\begin{array}{l}\text { ALT } \\
\text { (U/L) }\end{array}$ & $28.14 \pm 0.68^{c}$ & $43.58 \pm 0.87^{\mathrm{a}}$ & $36.91 \pm 0.98^{b}$ & $34.74 \pm 1.05^{\mathrm{b}}$ \\
\hline $\begin{array}{l}\text { T. bilirubin } \\
\text { (mg/dl) }\end{array}$ & $0.43 \pm 0.03^{\mathrm{d}}$ & $1.01 \pm 0.15^{\mathrm{a}}$ & $0.85 \pm 0.16^{b}$ & $0.72 \pm 0.19^{c}$ \\
\hline $\begin{array}{l}\text { Albumin } \\
(\mathrm{g} / \mathrm{dl})\end{array}$ & $3.36 \pm 0.18^{\mathrm{a}}$ & $2.18 \pm 0.15^{\mathrm{c}}$ & $2.94 \pm 0.15^{\mathrm{b}}$ & $3.17 \pm 0.19^{\mathrm{a}}$ \\
\hline $\begin{array}{l}\text { Cholesterol } \\
(\mathrm{mg} / \mathrm{dl})\end{array}$ & $65.32 \pm 3.87^{\mathrm{c}}$ & $84.37 \pm 4.97^{\mathrm{a}}$ & $76.13 \pm 5.01^{b}$ & $69.58 \pm 4.81^{\mathrm{bc}}$ \\
\hline $\begin{array}{l}\text { Triglycerides } \\
(\mathrm{mg} / \mathrm{dl})\end{array}$ & $75.39 \pm 2.15^{\mathrm{c}}$ & $114.05 \pm 3.11^{\mathrm{a}}$ & $96.13 \pm 3.01^{\mathrm{b}}$ & $80.59 \pm 2.76^{c}$ \\
\hline $\begin{array}{l}\text { HDL-Chol } \\
(\mathrm{mg} / \mathrm{dl})\end{array}$ & $48.23 \pm 2.54^{\mathrm{a}}$ & $31.31 \pm 2.39^{c}$ & $36.58 \pm 2.05^{b}$ & $37.49 \pm 1.87^{\mathrm{b}}$ \\
\hline $\begin{array}{l}\text { LDL-Chol } \\
(\mathrm{mg} / \mathrm{dl})\end{array}$ & $27.32 \pm 1.94^{\mathrm{d}}$ & $59.34 \pm 2.76^{\mathrm{a}}$ & $46.15 \pm 3.11^{\mathrm{b}}$ & $38.64 \pm 2.97^{\mathrm{c}}$ \\
\hline
\end{tabular}

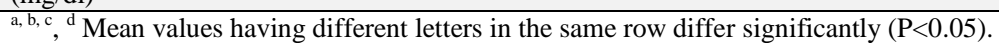

Histopathological effects of paracetmol and cinnamon treated groups on liver were shown in Figure (1). 
A
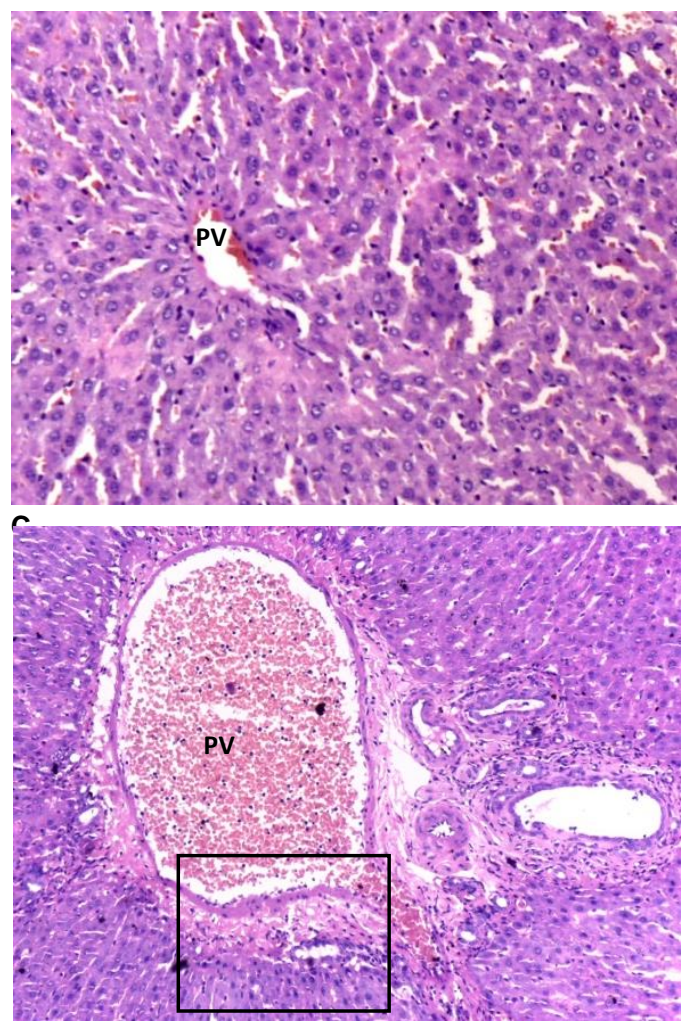

E

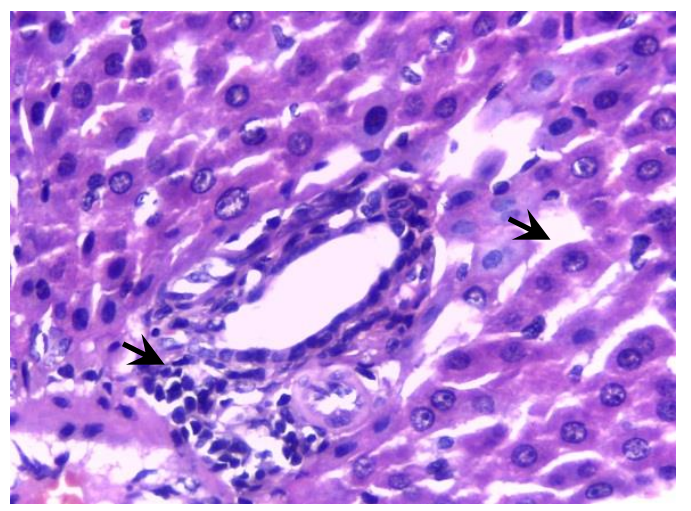

B

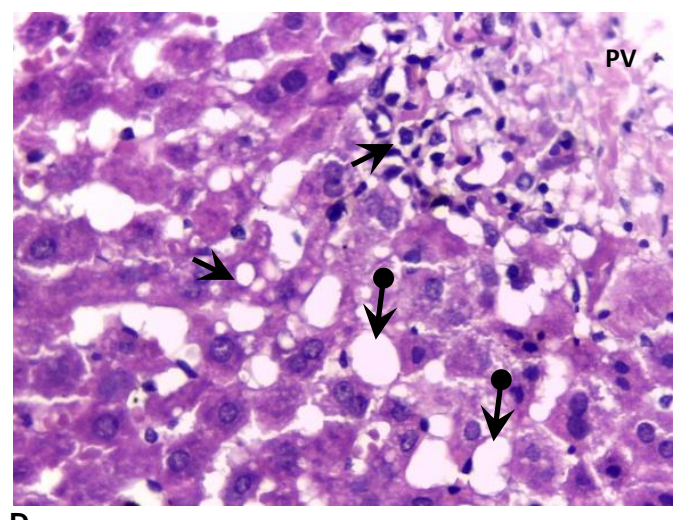

D

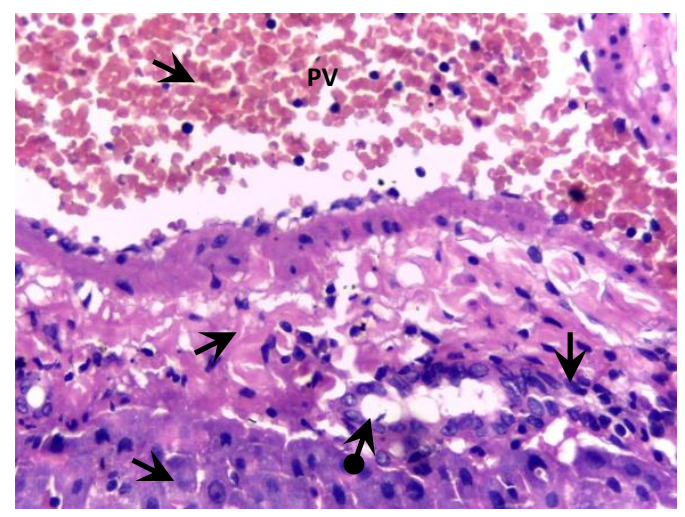

$\mathbf{F}$

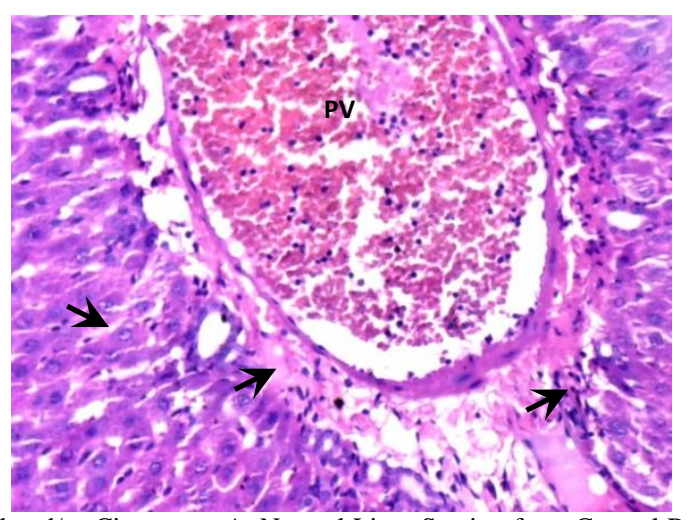

Fig. 1: Histopathological Changes in Liver after Treated with Paracetamol and/or Cinnamon. A: Normal Liver Section from Control Rat Shows Uniform Polyhedral Hepatocytes with Normal Sinusoids (X20). B (X40), C (X10), and D: Paracetamol Treated Rats Show Portal Vien Congestion, Sever Hydropic Degeneration (Signet Ring $\bullet \rightarrow$ ), Necrosis, Piknotic Nuclei, Lymphocytic Infiltration, and Fibrous Tissue Proliferation Around the Portal Vien. D: Black Square Magnification Shown in C. E (X40) and F (X20): Paracetamol+ Cinnamon Low and High Dose Treated Rats, Respectively, Show Mild Necrosis, Lymphocytic Infiltration, and Normal Sinusoids. (PV: Portal Vien; H\&E)

\section{Discussion}

Paracetamol, is one of the safest non-steroidal analgesicantipyretic drugs when used in recommended doses, but if administrated for long period, it produced a massive hepatic necrosis on chronic low dose or acute overdose (Bonkovsky et al., 1994).

Concerning serum biochemical parameters in relation to liver functions of paracetamol treated groups; a significant increase in ALT and AST levels were observed. These results agreed with a previous data (Sreedhar et al., 2011). These changes attributed to the formation of high amount of $\mathrm{N}$-acetyl-pbenzoquineimine. This acetaminophen metabolite is a major cause of hepatocellular damage and centrilobularhepatic necrosis (Diadelis et al., 1995). Declaring to bilirubin level, there was a significant increase in total bilirubin. These findings might be due to excessive release of triglycerides (Iweala and Osundiya, 2010). Also, a significant decrease in HDL-Cholesterol, which agreed previous result (Setty et al., 2007). The disturbance in HDL-Cholesterol attributed to overproduction of $\mathrm{H}_{2} \mathrm{O}_{2}$ generated during the cytochrome $\mathrm{P}_{450^{-}}$ mediated microsomal metabolism of paracetamol (Rajkapoor et al., 2008).

The present results showed that cinnamon extract ameliorates the biochemical alterations induced by paracetamol in rats. These findings are in accordance with the result of Moselhy and Ali (2009) who reported that the increase in serum ALT and AST of $\mathrm{CCl}_{4}$-intoxicated rats. Also, ethanolic extract of cinnamon induced suppression of increased ALT and AST activities.

Cinnamon produced significant decrease in triglycerides, total cholesterol, LDL-cholesterol and significant increase in HDLcholesterol concentrations in serum of cinnamon treated groups than recorded in control group. Also, improve the lipid profile after paracetamol toxicity. These results were consistent with those obtained by Khan et al., (2003) who reported that, administration of cinnamon at 1,3 , and $6 \mathrm{~g}$ doses/day caused a decreasein serum lipid profile in humans. The administration of cinnamon to mice reduced the lipid profile (Kim et al., 2006). Also, Shalaby and Saifan (2014) concluded that, cinnamon aquous ex- 
tract produced hypolipidemic, antidiabetic, hepatoprotective and anti-oxidant effects in diabetic obese rats.

The obtained histopathological results in this study were in agreement with Gad et al., (2013) who found that, liver of rat received paracetamol $1 \mathrm{gm} / \mathrm{kg}$. B. wt., 1 week post treatment, showing sever expression for Caspase- 3 in endothelial of the central vein and blood sinusoids with occasional marked expression in some hepatocytes. Also, showing hydropic degeneration of the hepatocytes in diffuse manner.

Extracts of cinnamon bark has revealed the presence of glycosides, coumarins, alkaloids, flavonoids, anthraquinone, tannins terpenoids and steroids (Shihabudeen et al., 2011). It is suggested in this study that the hepatoprotective of cinnamon aqueous extract is attributed to its antioxidant effects of flavenoids comoponents.

\section{Conclusions}

Aquoues extract of cinnamon produces a significant hepatoprotective effect in paracetamol-treated rats. Further investigations are required to study the mechanism action of cinnamon against paracetamol induced hepatoic toxicity.

\section{Conflict of interest}

The authors declare that there is no conflict of interests regarding the publication of this article.

\section{References}

[1] Abraham P. (2005) Oxidative stress in paracetamol-induced pathogenesis: (I) Renal damage. Indian J Biochem Biophys. ; 42:59-62.

[2] Ahmed M, Khater MR. (2001) Evaluation of the protective effect of Ambrosia maritime extract on acetaminophen-induced liver damage. J Ethnopharmacol. ; 75:169-174. http://dx.doi.org/10.1016/S0378-8741(00)00400-1.

[3] Bakkali F, Averbeck S, Averbeck D. (2008) Biological effects of essential oils - a review. Food Chem Toxicol; 46: 446-475. http://dx.doi.org/10.1016/j.fct.2007.09.106.

[4] Bonkovsky, H.L., Kane, R.E., Jones, D.P., Galinsky, R.E., Banner, R. (1994). Acute hepatic and renal toxicity from low doses of acetaminophen in the absence of alcohol abuse or malnutrition: evidence for increased susceptibility to drug toxicity due to cardiopulmonary and renal insufficiency. Hepatology 19(5): 1141-1448 http://dx.doi.org/10.1002/hep.1840190511.

[5] Carmo ES, Lima ED, de Souza EL, de Sousa FB. (2008) Effect of Cinnamomum zeylanicum blume essential oil on the growth and morphogenesis of some potentially pathogenic Aspergillus species. Braz J Microbiol; 39:91-97. http://dx.doi.org/10.1590/S1517. 83822008000100021.

[6] Diadelis, R., Jan, N.M., Commandeur, E.D., Nic, P.E.,Vermeulen. (1995). Mechanism of protection of Lobenzarit against paracetamol-induced toxicity in rat hepatocytes Environmental Toxicology and Pharmacology Section 293: 300.

[7] Gad FA, Abd Allah OA, Ayman Farid AS, Fararh KM (2013) Biochemical, Histopathological and immunohistochemical changes in paracetamol, fish oil and thioacetamide treated rats. Benha Vet J. $25(1) 18-28$

[8] Gruenwald J, Freder J, Armbruester N. (2010) Cinnamon and health. Crit Rev Food Sci Nutr; 50:822-834. http://dx.doi.org/10.1080/10408390902773052.

[9] Harries ML. (1989) Carleton's Histopathological Technique. $5^{\text {th }}$ ed. Oxford Univ. Press, New York, Toronto. P. 33-48.

[10] Iweala, E.E.J.,Osundiya, A.O. (2010). Biochemical, Haemayological and Histological Effectsnof Dietary Supplementation with leaves of GnetumafricanumWelw on Paracetamol induced Hepatotoxicity in rats. International Journal of Pharmacology 6(6): 872879. http://dx.doi.org/10.3923/ijp.2010.872.879.

[11] Jayaprakasha GK, Negi PS, Jena BS, Jagan Mohan Rao L. (2007) Antioxidant and antimutajenic activities of Cinnamomum zeylanicum fruit extracts. J Food Compos Anal; 20:330-336. http://dx.doi.org/10.1016/j.jfca.2006.07.006.

[12] Khan A., Safdar, M. Khan, M.M.A. Khattak, K.N. and Anderson, R.A. (2003). "Cinnamon improves glucose and lipids of people with type 2 diabetes," Diabetes Care, 26 (12) 3215-3218. http://dx.doi.org/10.2337/diacare.26.12.3215.

[13] Kim S.H., Hyun, S.H. and Choung, S.Y. (2006). Anti-diabetic effect of cinnamon extract on blood glucose in $\mathrm{db} / \mathrm{db}$ mice. Journal of Ethnopharmacology, $\quad 104, \quad(1-2) \quad 119-123$ http://dx.doi.org/10.1016/j.jep.2005.08.059.

[14] Mayuren C., Reddy V.V., Priya S.V., and Devi V.A., (2010) Protective effect of Livactine against $\mathrm{CCL}_{4}$ and paracetamol induced hepatotoxicity in adult Wister rats. North American Journal of Medical Sciences, (2) 492-495. http://dx.doi.org/10.4067/S071697602009000100009.

[15] Moselhy, S.S. and Ali, H.H. (2009). Hepatoprotective effect of Cinnamon extracts against carbon tetrachloride induced oxidative stress and liver injury in rats. Biol Res 42: 93-98.

[16] Muthuraman A., Sood S., and Singla S.K., (2011) the antiinflammatory potential of phenolic compounds from Emblica officinalis L. in rat. Inflammopharmacology, 19: 327-334. http://dx.doi.org/10.1007/s10787-010-0041-9.

[17] Nishida S, Kikuichi S, Yoshioka S, Tsubaki M, Fujii Y, Matsuda H. (2003) Induction of apoptosis in HL-60 cells treated with medicinal herbs. Am J Chin Med; 31:551- 562 http://dx.doi.org/10.1142/S0192415X03001211.

[18] Preuss HG, Echard B, Polansky MM, Anderson R. (2006) Whole cinnamon and aqueous extracts ameliorate sucrose-induced blood pressure elevations in spontaneously hypertensive rats. J Am Coll Nutr; $\quad 25: \quad 144-\quad 150$ http://dx.doi.org/10.1080/07315724.2006.10719525.

[19] Rajkapoor, B.; Venugopal, Y.; Anbu, J.; Harikrisshnan, N.; Gobinath, M. and Ravichandran, V. (2008). Protective effect of Phyllanthuspolyphylluson acetaminophen induced hepatotoxicity in rats. Pakistan. J. Pharm. Sci., 21(1): 57 -62.

[20] Setty, S.R., Quereshi, A.A., Swamy, A.H., TusharPatil, T., Prakash, T., Prabhu, K., Gouda, A.V. (2007). Hepatoprotective activity of Calotropisprocera flowers against paracetamol-induced hepatic injury in rats. Fitoterapia (78):451-454 http://dx.doi.org/10.1016/j.fitote.2006.11.022.

[21] Shalaby MA and Saifan HY (2014) some pharmacological effects of cinnamon and ginger herbs in obese diabetic rats J Intercult Ethnopharmacol. 3(4): 144-149.

[22] Shalaby MA, Hamowieh AR. (2010) Safety and efficacy of Zingiber officinale roots on fertility of male diabetic rats. Food Chem Toxicol. ; 48:2920-2924. http://dx.doi.org/10.1016/j.fct.2010.07.028.

[23] Shihabudeen, M.; Priscilla H.; Thirumurugan K. (2011). Cinnamon extract inhibits glucosidase activity and dampens postprandial glucose excursion in diabetic rats. Nutr Metab; 8:1-11.

[24] Sreedhar, V., Nath, L.K., Nath, M.S., RajaSekhar, K.K., Shankarananth, V. (2011). Hepatoprotective Activity of Vitextrifoliata roots against Paracetamol- Induced Hepatic Injury in rats. Journal of Pharmacy Research 4(2): 551-553.

[25] Subash Babu P, Prabuseenivasan S, Ignacimuthu S. (2007). Cinnamaldehyde-a potential antidiabetic agent. Phytomedicine; 14: 1522. http://dx.doi.org/10.1016/j.phymed.2006.11.005.

[26] Tung YT, Chua MT, Wang SY, Chang ST. (2008) Antiinflammation activities of essential oil and its constituents from indigenous cinnamon (Cinnamomum osmophloeum) twigs. Bioresour Technol; 99: 3908-3913. http://dx.doi.org/10.1016/j.biortech.2007.07.050.

[27] Yang YC, Lee HS, Lee SH, Clark JM, Ahn YJ. (2005) Ovicidal and adulticidal activities of Cinnamomum zeylanicum bark essential oil compounds and related compounds against Pediculus humanus capitis (Anoplura: Pediculicidae). Int J Parasitol; 35:1595-1600. http://dx.doi.org/10.1016/j.ijpara.2005.08.005. 